\title{
Chapter 17 \\ Developmental Trajectories of Political Engagement from Adolescence to Mid- Adulthood: A Review with Empirical Underpinnings from the German Peace Movement
}

\author{
Maor Shani, Daniel Horn, and Klaus Boehnke
}

\subsection{Introduction}

A politically efficacious, confident, and engaged citizenry is vital for achieving the ideals of democracy and strengthening democratic participation. The familiar observation that conventional participation in Western democracies is in decline, especially among young people (Levine, 2007; Norris, 2011), highlights the importance of engaging adolescents in politics even before they reach voting age. It is in the context of political experience and collective action that adolescents and youth take an active role as agents of social change and learn to be involved citizens in the community (Flanagan, 2013). Moreover, studies have found that an increase in political efficacy following activism is larger for youth from disadvantaged groups (Flanagan, 2009). Thus, civic and political activism among young people has the potential to facilitate political equality, by merit not only of its capacity to mobilize citizens earlier in the life course but also to do so among those segments

Klaus Boehnke's contribution to this chapter was in part prepared within the framework of the Basic Research Program at the National Research University Higher School of Economics (HSE) and supported within the framework of a subsidy by the Russian Academic Excellence Project "5-100."

\footnotetext{
M. Shani $(\bowtie)$

Jacobs University Bremen, Bremen, Germany

e-mail:m.shani@jacobs-university.de

D. Horn

University of Strathclyde, Glasgow, UK

K. Boehnke

Jacobs University Bremen, Bremen, Germany

National Research University Higher School of Economics, Moscow, Russia 
typically underrepresented in political contests - precisely those segments of society which stand to benefit from increased attention from policy makers. Political science research from the "political culture" paradigm offers empirical evidence to this fact in abundance (Bogaards \& Deutsch, 2015; Welzel \& Deutsch, 2012).

Political socialization results from the process by which people acquire political attitudes and worldviews, as well as the patterns by which they engage in civic and political life (Easton, 1968). In political socialization theory, adolescence and youth are crucial periods. The formative years hypothesis (Jennings \& Niemi, 1981) points to the importance of one's adolescent and youth years (between 15 and 25), as a period where long-term patterns of political behaviors are formed and during which individuals acquire the basic cognitive skills for political mobilization later in life. ${ }^{1}$ Civic identity and patterns of political participation are shaped as adolescents explore their identity, seek purpose, and determine their beliefs and commitments with regard to themselves and others (Flanagan \& Tucker, 1999).

It is, therefore, reasonable to expect that adolescent-age experience will be decisive in determining the formation of political identities and lifelong trajectories. Still, it is not unlikely that these patterns will change as people go through different stages of life and encounter the dynamic political world or other influences. Indeed, some have also argued that political learning is a nonlinear, lifelong process, as adults continue to craft their political perspective throughout the lifespan (Quintelier, 2015a).

\subsection{Intergenerational Transmission of Political Worldviews and Participation and Their Stability Across the Lifespan}

Self-identification on the left-right continuum is a prominent indicator of political worldviews. This spectrum is significant in Western political systems beyond its symbolic value, as it constitutes a framework through which citizens interpret political messages, form positions on particular issues, and participate in politics (Inglehart \& Klingemann, 1976; van der Eijk, Schmitt, \& Binder, 2005).

How is political orientation on the left-right dimension formed in adolescence, and how does it change throughout life? Theories on youth political engagement emphasize the importance of socialization agents, mainly family, peers, school, social organization, and mass media. More recently, emphasis has been given to the active role adolescents themselves play in their own development in the political sphere, especially during late adolescence and youth (Amnå, 2012). Since the family generally constitutes a stable base in the political socialization and identitybuilding of children and adolescents, ideological inclination is at least partially

\footnotetext{
${ }^{1}$ It is possible to distinguish adolescence and youth as overlapping stages as defined by the United Nations; www.un.org/esa/socdev/documents/youth/fact-sheets/youth-definition.pdf
} 
molded by one's parents, through the process of intergenerational transmission of political traits within the family. ${ }^{2}$ Take, for instance, a large panel study in the USA stretched over the three last decades of the twentieth century, confirming that parents play a central role in their offspring's political learning (particularly in their electoral behavior and party preference), with generally strong correlations between parents' and children's attitudes (Jennings \& Niemi, 1974; Jennings, Stoker, \& Bowers, 2009). More recently, Rico and Jennings (2016) analyzed data on Catalan parentchild pairs and found support for direct transmission of political worldviews from parents to children, as suggested by social learning theory. Small to moderate effects of intergenerational transmission were also found for political interests, political knowledge, and political efficacy (Jennings et al., 2009).

A more structural approach posits that political orientation may also be inherited (indirectly) through social positions and statuses (e.g., class, race, and religion), as well as shared characteristics such as social and cultural capital, all of which can independently affect adolescents' left-right location (Rico \& Jennings, 2016; Vollebergh, Iedema, \& Raaijmakers, 2001). Research has demonstrated, for example, that the transmission of political values is more intensive in families with more resources and where children are encouraged to participate in politics and gain political knowledge (Verba \& Nie, 1972).

Whether transmission occurs directly or indirectly, individual and contextual factors also exist which facilitate or hinder political similarities between parents and children. Research has recently identified moderators of intergenerational transmission. It has been found that the association between the political identification of parents and their children increases when there is parental agreement on ideological orientation (Jennings et al., 2009); when parents demonstrate higher levels of political participation and the family has an active political climate; and when adolescents feel closeness toward their parents and there are intense and positive relationships within the family (Jennings \& Niemi, 1974). Closeness plays a particularly unique role as regards gender; children are likely to embrace the political stance of the parent that is perceived as particularly competent or similar to themselves. Indeed, studies have found stronger transmission within same-sex dyads and from father to son (Boehnke, 2017; Portney, Eichenberg, \& Niemi, 2009).

Still, there are reasons to assume that even if political orientations and behaviors are transmitted from parents to children during adolescence, individuals may embrace different political perspectives and patterns of engagement as they transition to adulthood. This is, to some degree, supported by trends of ideological dissimilarities recently found in studies of parent-child dyads. Corbetta, Tuorto, and Cavazza (2013), for example, report discontinuities in parent-adolescent concordance on left-right self-placement in Italy in both 1975 and 2010. Whereas in

\footnotetext{
${ }^{2}$ The theoretical foundations of intergenerational transmission of political attitudes and behaviors are rooted in social learning theory (Bandura, 1969), which asserts that owing to a lack of ability and knowledge, children and adolescents observe, imitate, internalize, and ultimately reproduce the attitudes and behaviors which are reinforced by key agents of socialization, figures who function as role models.
} 
the mid-1970s, diverging orientations were characterized by right-wing parents and left-wing children, by the early 2010 s, adolescents were found to embrace rightwing politics more than their parents.

In this context, generational replacement theory (Delli Carpini, 2006) emphasizes the importance of the sociopolitical context in which political socialization occurs. Historical events that occur during the coming of age leave a substantial formative influence on youth. Political change is partially determined by the degree to which youth adopt the view of their parents' generation or embrace distinct collective perspectives. Patterns of discontinuity in political engagement and views are therefore possible and will intersect with historical and societal changes.

Finally, political scientists have relied on developmental and rational choice models to question the persistence of early-acquired attitudes and their stability throughout life (Sears \& Funk, 1999). Flanagan (2009) noted that in the transition from adolescence to adulthood, young people are characterized by a greater independence of thought and greater self-determination, and therefore their adulthood political views often divert from those of their parents. Nevertheless, common models in political science still predict persistence and relative stability in political predispositions across the lifespan. Sears and Funk (1999), for instance, examined trajectories in partisan attitudes in a large-sample longitudinal study among Americans from early adulthood to retirement age reveal substantial stability in attitudes across nearly four decades of data, alongside small but consistent changes among a considerable minority. Similarly, Becker and Saalfeld (2006) use panel data from the German Life-Course Study collected in the 1980s and 1990s to examine changes in party identification among German citizens, finding (particularly in the Western part of the country) an overall stability in party identification, despite increasing individual-level volatility over time. The debate remains as to whether and how political dispositions persist over the life course.

\subsubsection{Potential Longitudinal Effect of Activism on Future Political Engagement}

Political leanings are but one facet of the development of agency among adolescents and youth. Such preferences must be complemented with action. While it is common to limit such action to voting, for instance, it is also important to recognize other forms in which these preferences are actualized. In this regard, it has been hypothesized that the influence of parents on their children's political agency goes beyond the transmission of political worldviews. Although most research has focused on transmission in this area, scholars have also recently explored the effect of parental political participation on their offspring's patterns of engagement (Amnå, 2012; Jennings et al., 2009; Quintelier, 2015b). Parents shape not only the preferences of their offspring, according to this line of research, but also the engagement with the political world. For example, it has been found that children 
whose parents are civically involved are more likely to be politically engaged as adults (i.e., more likely to vote, volunteer, and be involved in political campaign and organization) compared to children whose parents were more disengaged from politics (McFarland \& Thomas, 2006). Even children who frequently discuss politics with their parents or are exposed to political discussion at home are more likely to be politically active as they become adults (e.g., McIntosh, Hart, \& Youniss, 2007). Quintelier (2015b) found that the intention to participate in politics is transmitted from parents to children indirectly, through a politicized family environment, measured by level of political discussion, more so among families of higher socioeconomic status.

However, parental effects on political engagement may be rather limited in scope and duration, since the intensity of parent-child relationship changes over the life course. Young adults elaborate their personal and social identities through multiple interactions outside the family (Erikson, 1968), in a process that weakens the influence of previously important role models. Moreover, in the framework of extended transition to adulthood that characterized youth in the late twentieth century and in our current time, other nonfamilial socialization agents often take the lead in determining political trajectories of emerging adults (Arnett, 2006). In line with this theoretical postulation, Quintelier (2015a, 2015b) explored the longitudinal effects of different agents of socialization on the development of Belgian adolescents' political participation. She found that parents and schools also contribute to political participation, although to a lesser extent than peers and voluntary associations.

In exploring diverse pathways of political socialization, scholarly attention has also been paid to the role of social networks and social media, which increasingly replace traditional social ties to families, institutions, and peers in shaping the political attitudes and engagement of young citizens (Loader, Vromen, \& Xenos, 2014). Vraga et al. (2014) demonstrated how social media reinforces the role of peer relationships in political socialization during the 2008 US elections, as it encouraged civic and political talk among peers, thereby increasing their autonomy in shaping their own political orientations. Finally, Ojeda and Hatemi (2015) convincingly argue that transmission studies should also emphasize the active role offspring play in creating similarity between parents and children through influencing political convictions and behaviors of their parents.

Social psychology has traditionally focused on unraveling the psychological determinants and motives for political engagement and collective action (see Thomas \& Louis, 2013) while rather neglecting the short- and long-term outcomes that may be associated with such endeavors. However, in recent years, a gradual increase in research on the psychological relationships, and benefits, of political activism and other forms of civic engagement has begun to emerge. In terms of impact on psychological and identity constructs, activism has been found to be positively related to self-esteem, physical and mental health, well-being (Boehnke \& Wong, 2011), social support and cohesion, and other psychological outcomes. For example, the effect of activism on long-lasting political efficacy and 
empowerment has been linked to positive emotional responses to collective actions, such as pride (e.g., Drury \& Reicher, 2009; Tausch \& Becker, 2012). Nevertheless, the experience of failure or defeat was also found to lead to negative emotions such as upset and fear, which ultimately disempower activists and reduce their perceived efficacy (Drury \& Reicher, 2005).

Youth activism has also been found to be associated with personal growth, including creative thinking (Becker, 2012), higher self-confidence (Shriver, Miller, $\&$ Cable, 2003), and lower self-derogation (Kaplan \& Liu, 2000). In concordance with such positive psychological benefits, a body of research suggests that activism can have both short- and long-term effects on well-being (Boehnke \& Wong, 2011; Klar \& Kasser, 2009). For example, Boehnke and Wong (2011) found that political engagement among youth was negatively associated with what they called microsocial (personal) worries and positively associated with happiness in adulthood.

Activism during youth and early adulthood was also found to have biographical consequences for activists later in life. In terms of marital status and children, activists were more likely to remain single later in life and to have less children. In this domain, activism was also found to have a differential biographical impact on men and women. For example, Franz and McClelland (1994) found that women peace activists were found to choose an independent and career-pathed lifestyle, which led to higher incomes compared to non-activist women, while men activists entered the job market later and struggled occupationally. ${ }^{3}$

Research in recent decades has identified growing socioeconomic gaps in levels and forms of civic and political participation among youth from different social and ethnic background (e.g., Verba, Scholzman, \& Brady, 1995). Evidently, young people from higher socioeconomic status encounter more institutional opportunities for activism (e.g., extracurricular activities during high school and college, community organizations, voluntary service programs) compared to youth from disadvantaged communities, who belong to institutions that provide less structural opportunities for socialization into political life (Flanagan \& Levine, 2010; Settersten Jr, Furstenberg, \& Rumbaut, 2008). Studies have also recently revealed the potential benefits of youth activism in resource-stressed communities. By taking a role as agents of change, whether to improve their status or in response to historical and national events (such as democratic deficits and wars), adolescents and youth from disadvantaged communities can turn negative emotions into motivation for social change, thereby increasing their political efficacy and minimizing political inequalities (Flanagan, 2013).

One additional possible outcome of activism pertains to activism itself: one's own involvement in activism may impact one's motivation and continuous involvement for civic and political engagement across the lifespan. According to this hypothesis, being active in youth may be a precursor to civic engagement in adulthood. Accordingly, Verba et al. (1995) argued that youth activism sets one on a

${ }^{3}$ For a review and classification of biographical consequences of activism, see Vestergren, Drury, and Chiriac (2017). 
recruitment trajectory, as opportunities for sustainable engagement in organization are linked to previous engagement. The implications of this snowballing is particularly relevant for community empowerment, notably as programs aimed at addressing the basic needs of the poor are positively correlated with those constituents being active in the political arena (Verba, 2003).

The assertion of a downstream effect of activism in previous periods of life, however, still lies on thin empirical ground. Evidently, most research on activism across the lifespan is not longitudinal in its scope. Relying on cross-sectional and retrospective studies is detrimental to causal attribution: it could be that the aforementioned positive outcomes of activism merely characterize individuals who are prone to activism. In particular, longitudinal research on the impact of activism and civic engagement during adolescence on future engagement has been scarce. One such study by Verba et al. (1995) indicates that involvement in communitybased organizations during adolescence predicts compatible civic engagement in adulthood. Similar results on the persistency of activism were obtained by Abramowitz and Nassi (1981) and Fendrich and Lovoy (1988). ${ }^{4}$ In contrast, results from data collected among children and adolescents in West Germany from the mid1980 s to the early 2000s found that initial engagement with activities of the peace movement does not predict political activism in early adulthood. ${ }^{5}$ Rather, it was found that cognitive involvement in political issues at an early age (e.g., factual knowledge) as well as emotional involvement (mainly being worried or stressed regarding societal conditions) predicts mobilization in early adulthood (Boehnke \& Boehnke, 2005).

Although longitudinal research has yet to be sufficient, possible mechanisms underlying the long-term impact of civic and political engagement on further engagement have recently been delineated, either through qualitative research or by empirical testing in observational and even experimental research. Individual experiences in activism may feed back into intentions for continuous engagement through arousing strong emotions, altering efficacy expectations, and strengthening collective identification. Due to the psychological benefits of collective action on, for example, well-being, activists may be encouraged to continue to engage in protest where they experience positive emotions as a result of previous involvement (Ballard \& Ozer, 2016).

In a series of correlational and experimental studies, Becker and Tausch (2015) have shown how psychological consequences of participation in collective action, and particularly emotions, shape and reshape motivations to engage in further actions. In particular, they argue that collective action participants can simultaneously experience positive self-directed emotions and negative outgroup-directed emotion, and both emotional orientations enhance motivation for future action. Moreover,

\footnotetext{
${ }^{4}$ Following 15 activists from the 1960s Berkeley free speech movement over 11 years and political engagement in adulthood among former adolescent activists in the 1960s American civil rights movement, respectively

${ }^{5}$ The same study as the one to be present in the second part of this chapter, but then with a larger sample, due to higher retention rates for earlier waves of the longitudinal study
} 
they suggest that successful experiences with collective actions instill (ingroupdirected) pride among activists, while the experience of failure often breeds (outgroup-directed) anger, and both emotions increase commitment to collective action. Therefore, what determines continuous participation in collective action is not whether the preceding action was successful or not but rather how people experience, react, and frame its outcome. The long-term effect of activism on further engagement can also stem from growing identification with the group or organization and its social and political goals. Embracing collective identity, and even fusing one's self-identity to that of the group (Fischer, 2001; Kunst et al., 2018), can motivate an individual to continue acting for the collective cause through normative and nonnormative means.

One noticeable mediator of the effect of activism on future engagement is political efficacy - feelings of competence and motivation to engage in politics and to have an impact on the political process (Beaumont, 2010). It is mainly through political efficacy that the interplay between psychological and behavioral processes in political life is manifested. Blackwood and Louis (2012) found that peace activists' intention to engage in collective action was linked to group efficacy and perceptions of the individual benefits of participating in political activities. A successful collective action will, therefore, enhance one's efficacy and thereby one's continued engagement.

Beaumont (2010) explains that real-world political experience by youth can serve as skill-building experience for political mastery. Activism may provide young people from diverse backgrounds with models of involvement and enable them to feel connection to others. Becoming involved in collective action can also provide adolescents with social encouragement and help them build inclusive and supporting relationships and networks. By becoming active, young people can feel part of a larger community, which may increase their sense of security while engaging in political action, further strengthening bonds that themselves may seep into future policy articulation.

Finally, following collective engagement in civic or political life, adolescents were found to develop a capacity to challenge existing relations and commitment to reshaping the social world around them (Drury \& Reicher, 2009). Evidence suggests activism may be an empowering experience for adolescents, instilling in them a resilient political outlook (Beaumont, 2010). Even in the face of defeat, activists who identify strongly with the movement are able to transform disempowering experiences to action motivation (Barr \& Drury, 2009).

Research has also demonstrated durable effects of activism on efficacy. For example, civic and political activity in school has been found to enhance youth's belief in their individual and collective ability to bring about societal change, which may in turn stimulate long-lasting participation (Flanagan, 2013). Since the acquisition of political efficacy occurs mainly in early and mid-adolescence, we may expect early political engagement to predict continuous involvement, even all the way through early and mid-adulthood. 


\subsection{Examining the Relationship Between Political Orientation and Engagement Across Adolescence and Adulthood Through a German 30-Year Panel Study}

The literature reviewed above highlights important yet rarely addressed questions that stem from the intersection between political socialization and developmental psychology, notably the durability and stability of political attitudes and engagement from adolescence to adulthood. To what extent does engaging in political activism as an adolescent contribute to activism into and during adulthood? To what extent does parental activism in one's adolescence uniquely influence one's own engagement in politics decades later? Finally, to what extent do political predispositions remain stable in adulthood while being affected by early-life political experiences? What is needed is data over a sufficiently long period, including items measuring variables associated with this agency.

Unique data collected in Germany allows us the opportunity to explore these questions and to examine stability and change in political engagement over more than 30 years. The longitudinal study under the title "Life under Nuclear Threat" commenced in 1985, against the background of Cold War tensions, notably the deployment of missiles in Germany in the framework of rearmament, and amidst fears of imminent nuclear war (Petri, Boehnke, Macpherson, \& Meador, 1986). Concerned about the impact of events on children's and adolescents' mental health, a research team in West Berlin began the documentation of existential anxieties and mental health indicators among a convenience sample of young Germans (ages 8 to 23), obtained through controlled snowballing in cooperation with individuals and groups related to the peace movement. Many of the participants took part in the West German (ultimately unsuccessful) peace movement, participating in resistance activities, including mass demonstrations (for more details, see Boehnke \& Boehnke, 2005; Boehnke \& Wong, 2011).

Since the onset of the study, ten waves of data collection have been conducted over a period of three decades, with an interval of approximately 3.5 years between data-gathering waves. As expected, attrition has been substantial, though not particularly so compared to similar research endeavors. In the second wave of data collection, when the study "gained" its longitudinal scope, 837 individuals (of 1492 who left their addresses in Wave 1) participated. In the 10th wave in 2016/2017, 242 participants remained (a bit less than 30\%). Despite this, attrition bias was not detected in previous publications (Boehnke \& Wong, 2011).

Patterns of political orientation and engagement have been explored using structural equation modeling (SEM) techniques on data collected in three out of ten waves of the study: Wave 2 (W2) in 1988/1989, Wave 8 (W8) in 2009/2010, and the most recent Wave 10 (W10) in 2016/2017. Early-life engagement in politics has been selected from the second and not the initial wave of data collection, under the assumption that activism in late adolescence will reflect individual 
choices to a larger extent than in early adolescence (when, e.g., parents may have been "dragging" their children to demonstrations or engagement was probably more opportunistic in nature). In research addressing a similar topic, namely, the predictability of Wave 8 political engagement on the basis of several indicators from Waves 1 and 2, Boehnke, Sohr, and Stromberg (2016) showed that predictors from Wave 2 performed better as predictors of later behavior than predictors from Wave 1. Nevertheless, some of the respondents were in their early adolescence even during the second wave of data collection, and therefore age has been controlled for in all analyses. Data is then included from two recent waves in order to examine how early-life engagement predicts political orientation and engagement in adulthood. This allowed us to examine more complex longitudinal effects and thus strengthen the causal attribution of our results. Moreover, it enabled us to examine possible instabilities and trends in political orientation and engagement during the period of mid-adulthood itself.

In total, 242 respondents completed all three waves. Among them, 59.1\% were female and $40.9 \%$ male. The average age of the respondents was roughly 17.5 in W2 (an age which can be referred to as "late adolescence"), 38.5 in W8 ("late 30s" mid-adulthood), and 45.5 in W10 ("mid 40s" in mid-adulthood), with age varying between 39 and $54(S D=2.54)$. There was no difference in the average age between men and women, $t(240)=-1.36, p=0.18$. The average income of respondents in 2017, according to self-reports, was 4016 Euros per month, approximately twice the average monthly income in Germany (about 2200 Euro). Moreover, participants were also more educated on average than the wider German population, with approximately $83 \%$ holding a German Abitur, a certificate of tertiary education entrance qualification only held by roughly $40 \%$ of their birth cohorts (Boehnke $\&$ Boehnke, 2005).

We use two measures of political engagement from W2. One's own activism in adolescence is measured by a single-item, dichotomous measure "Have you been active in the peace movement since you took part in the first study (1985 and later)?" with options yes and no. To measure parental activism, respondents were asked to indicate whether their parents "have already been active in the peace movement" without limiting the activity to a certain period, with options yes and no.

Two single-item measures of political orientation and engagement were used both in W8 and W10. To obtain political orientation, participants were asked to place themselves on a discrete 10-point left-right scale ( 1 = extreme left, $10=$ extreme right). Similar measures are frequently employed in studies of political and peace psychology to obtain general personal political preferences. Finally, to measure political engagement in adulthood, participants ranked their engagement on a 4-point scale with the following markers: $0=$ I have no interest in politics; $1=I \mathrm{am}$ not particularly interested in politics; 2 = I am interested in politics, but I am not active myself; and $3=I$ am interested in politics and actively involved. Both measures were used as continuous in the analysis.

As is common in many longitudinal studies, there was a considerable amount of missing data on single items. In order to increase the power of our analysis, and to 
Table 17.1 Mean values and standard deviations (in parentheses) for political orientation and political engagement in Wave 8 and Wave 10 for all participants and by gender, orientation, and activism groups

\begin{tabular}{l|l|l|l|l|l}
\hline Grouping variable & & \multicolumn{3}{l|}{ Political orientation } & \multicolumn{2}{l}{ Political engagement } \\
\hline & & Wave 8 & Wave 10 & Wave 8 & Wave 10 \\
\hline All participants & N=242 & $4.02(1.42)$ & $4.70(1.71)$ & $1.80(0.59)$ & $1.66(0.66)$ \\
\hline Gender & Female $(59.1 \%)$ & $3.87(1.24)$ & $4.45(1.46)$ & $1.69(0.63)$ & $1.64(0.66)$ \\
\hline & Male $(40.9 \%)$ & $4.22(1.63)$ & $5.07(1.96)$ & $1.95(0.47)$ & $1.68(0.66)$ \\
\hline Political orientation $^{\text {a }}$ & Left (71.1\%) & $3.45(1.02)$ & $3.86(1.07)$ & $1.85(0.57)$ & $1.63(0.69)$ \\
\hline & Right $(28.9 \%)$ & $5.40(1.31)$ & $6.79(1.05)$ & $1.67(0.61)$ & $1.71(0.59)$ \\
\hline Own activism $^{\text {b }}$ & Non-active (63.2\%) & $4.35(1.42)$ & $5.18(1.68)$ & $1.71(0.56)$ & $1.62(0.60)$ \\
\hline & Active (36.8\%) & $3.45(1.23)$ & $3.88(1.44)$ & $1.97(0.60)$ & $1.73(0.77)$ \\
\hline Parental activism $^{\text {b }}$ & Non-active (57.4\%) & $4.48(1.37)$ & $5.26(1.65)$ & $1.73(0.56)$ & $1.67(0.63)$ \\
\hline & Active (42.6\%) & $3.39(1.24)$ & $3.96(1.48)$ & $1.92(0.63)$ & $1.64(0.73)$ \\
\hline
\end{tabular}

Note: High scores are indicative of higher level of political engagement and more right-wing attitudes

${ }^{a}$ Midpoint split of Wave 10 measure

${ }^{\mathrm{b}}$ Dichotomous measures in Wave 2

facilitate an analysis based on advanced statistical procedures, we impute missing data using AMOS' built-in maximum likelihood algorithm. ${ }^{6}$

Table 17.1 presents means and standard deviations for the study variables by gender, political orientation (median split), and self- and parental activism groups. We first examined general trends in levels of political engagement and orientation between the two recent waves. Analyses of variance revealed a significant decrease in average levels of political engagement between W8 and W10. Moreover, there is evidence of a significant main effect of gender and, more importantly, a significant interaction between gender and time. In their late $30 \mathrm{~s}$, men were on average more politically engaged than women (see Table 17.1). However, 7 years later, women's engagement remained stationary, while men's engagement decreased significantly. Moreover, among both men and women, there was a significant shift to the right between W8 and W10.

In order to explicate the relationship between early-life activism and adulthood political engagement and worldviews, and to examine the extent to which these relationships are different for men and women, we fitted a multiple group structural equation model. Insignificant paths in both groups were constrained to be equal to zero to achieve a parsimonious yet well-fitting model. The model integrates a crosslagged analysis suitable for analyzing panel models with repeated measures (W8 and W10 political orientation and engagement). Finally, age is included in the model as a control variable to account for age variations among participants.

Initially, we fitted an unconstrained model. in which all structural paths were allowed to vary across groups (Fig. 17.1). The obtained model was well fitting

\footnotetext{
${ }^{6}$ When subsequently reporting results, we omit most statistical details for the sake of brevity and readability. A full version of the current chapter, including all statistical evidence in detail, can be obtained from the corresponding author.
} 


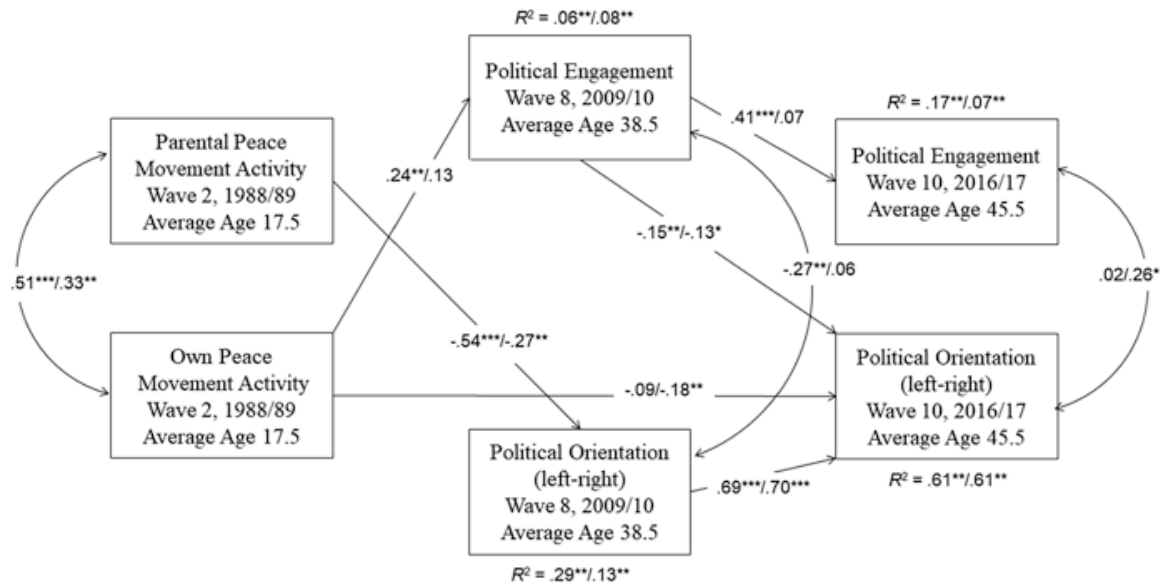

Fig. 17.1 Multiple group path model is displayed with standardized coefficients for women/men. $* p<0.05, * * p<0.01, * * * p<0.001$. Age is included in the model as a covariate of Wave 2 variable and as a predictor of Wave 8 and Wave 10 variables, but is not displayed for purposes of presentation

according to various indices of goodness of fit. Next, we constrained all regression weights to be equal for men and women. Results suggest that the model is significantly different for men and women. Consequently, we conducted a path-by-path analysis in order to find where men and women differ on specific paths.

First, we found a significant and positive relationship between adolescence-time activism in the peace movement and parallel parental activism, for both women and men. This can serve as initial evidence that political activism was intergenerationally transmitted among our peace movement sympathizers before or during late adolescence.

Second, early-life activism in the peace movement positively predicted late-30s political engagement among women, but interestingly not among their male counterparts. Third, we found that one's own peace movement activism in adolescence predicts more left-leaning attitudes at roughly mid-40s, but only among men.

Fourth, the model indicates that parental involvement in the peace movement three decades previously exhibited no significant effect on current political engagement. It did, however, significantly predict political orientation in adulthood: Among both men and women, having activist parents during adolescence is associated with being more leftist in late 30s. Furthermore, parental activism predicted political orientation in the mid-40s indirectly, via political orientation in late 30s, for both women and men. These results indicate that participants with peace activist parents increased their left-leaning orientations in adulthood.

Fifth, the cross-lagged relationship between political orientation and engagement in adulthood showed that for both men and women, higher engagement in the late 30 s predicted left-leaning attitudes at mid-40s, while political orientation in late 30s had no significant effect on later engagement. Even during adulthood, 
sustained political interest and/or activism can buffer against the observed slip to the right side of the political spectrum.

Finally, a differential relationship pattern emerged between political orientation and political engagement within each gender group during middle adulthood. Among women, a stronger leftist orientation was associated with higher engagement in politics in their late 30s, but not in their mid-40s; the difference in W8 and W10 covariances between political orientation and engagement among women was significant. The reverse effects were found among men -i.e., no association between engagement and orientation in their late 30s, with stronger right-leaning orientation associated with higher engagement in their mid-40s. In other words, left-leaning women were more active than right-leaning women in their late 30s but not in their mid-40s, while right-leaning men were as active as left-leaning men in their late 30 s, but more than the latter 7 years later.

\subsection{Discussion}

It is evident that literature in developmental, political, and peace psychology on processes of political socialization, with a focus on intergenerational and lifespan development on political worldviews and active participation in politics, remains an under-explored area of research. The empirical examination of the topic here, utilizing a remarkable longitudinal dataset collected over more than three decades among West Germans who were adolescents in the 1980s, provides some headway into this area of scholarship.

By employing analyses of longitudinal effects, we are able to explore potential causal effects in political attitudes and behaviors and thereby make an important contribution to a research field with a considerable and detrimental dearth of longitudinal data. Moreover, we demonstrate differential effects and trends for women and men, a potentially significant contribution to the understanding of gendered processes in political socialization and lifespan development, and one which should be explored further in future studies.

The findings offer several insights into the way early-life political engagement may be related to adulthood engagement and the way political orientation and engagement interact in adulthood. This is true both in the particular context of German peace movement sympathizers and activists and potentially in more general terms. First, we find evidence of a lasting effect of early-life activism on political engagement in adulthood: West German peace activists, especially women, maintained their commitment to political activity from late adolescence to midadulthood. This confirms, at least for female activists, the assertion that activism in adolescence does not only increase further political engagement in the short run but also in a sustainable way (Flanagan, 2009, 2013; Verba et al., 1995). With some caution, we can report that female adolescent activists are more likely to be adult activists compared to female adolescents who stay away from political activities. 
From a policy perspective, this empowerment at early ages translates into the capacity to influence the policy agenda in ways that may have knock-on effects for future cohorts.

For the time being, we can only speculate about reasons for the "gendered" results. We find it plausible to assume that the gender difference has more to do with the participants' individual "fertility history" - that is, when in the life course, have participants become parents themselves? We presume this to have a gendered impact on political involvement among men and women. Men, on average, become a parent together with women, who are younger than they are. This might keep both away from politics at different times of their individual lives and with political demands that are in line with their life-course situations. Childcare traditions may also, however, have a more direct "push" effect on women than men as regards engagement in politics (e.g., topics like children's rights and even peace may carry more salience). While data on fertility histories are available from the project, they could not be analyzed for the current chapter; further research is needed to unpack potential relationships.

It is, of course, important to consider that the prediction of adulthood engagement by one's involvement as an adolescent may merely point out a selection effect. Research already suggests that volunteers and non-volunteers hold different personalities and values (Matsuba, Hart, \& Atkins, 2007). Moreover, Boehnke and Wong (2011) note that active youngsters in the panel study were already characterized by better mental health than their non-active counterparts in the onset of research.

Second, the positive relationship between adolescents' own activism in the peace movement during the second half of the 1980s (assuming it was voluntary) and their parents' involvement in that movement may serve as initial evidence that political activism was directly or indirectly transmitted from parents to children. Pertaining to sustained effects, we find that parental peace activism during adolescence has a small effect on engagement in people's late 30s; however, this effect dissipates by the time participants reached their mid-40s. Nevertheless, there was no evidence of traces of intergenerational transmission of political engagement more than 30 years after the end of adolescence.

Third, we do find a positive relationship between parental activism in adolescence and adulthood political orientation. This may be interpreted through the framework of intergenerational transmission, as opposed to the case of engagement noted above. Although we did not include a measure of parental (or self) left-right orientation in adolescence, it is plausible that active parents leaned more to the left than non-active parents at the peak of peace activism in the 1980s. If this is true, this finding can be seen as corroborating a considerable long-term effect of intergenerational transmission on political attitudes. Moreover, it was previously found that politically engaged parents are more likely to transmit their political perceptions to their offspring (see also Jennings et al., 2009). It is therefore possible that levels of parent-child ideological continuity increased with higher parental politicization, contributing to the positive and lasting relationship between parental behavior and children's attitudes. It may also be the case that those exposed to the agency reinforcing impact of activism may internalize the possibility, and indeed desirability, of change than their counterparts. 
Fourth, our analysis also revealed interesting findings regarding recent trends in political worldviews and engagement among Germans who grew up in West Germany during the Cold War and were in one way or another attached to the peace movement. Although men and women were active in the peace movement in similar proportion as adolescents, we find that, in their mid-30s, men were slightly more engaged than their female counterparts. Previous studies also find that women are, in general, less interested and active in politics compared to men (e.g., Childs, 2004). In addition, during mid-adulthood, levels of political engagements decreased among men and among participants with left-leaning orientations. Recent findings from the USA also suggest a gradual decline in civic and political engagement along the life course (e.g., Jennings \& Stoker, 2004).

Quite interestingly, while women were more left-leaning than men in the beginning of the current decade, a trend of increasing right-leaning orientations is observed for both genders in the course of the decade. It is not clear to us whether the increase in rightward identification is rooted in universal lifespan or generational processes or is part of an overall conservative trend in the German society in recent years, as well as in other parts of the Western world. It is possible that this trend reflects the widely observed increasing support for far-right parties in Germany, such as Alternative für Deutschland (AFD), against the background of growing anti-immigration sentiments amidst recent waves of immigration into the country (Otto \& Steinhardt, 2017).

That being said, we also find that (among men) adolescent activism is linked to left-leaning attitudes in adulthood, and parental activism in adolescence is consistently linked to left-leaning attitudes in adulthood for both genders. More importantly, those who were active and whose parents were active demonstrate relative resistance to the right-wing trend. These effects reveal a potentially important function of early-life activism and one which has clear policy implications: it seems possible that adolescent involvement, as well as sustained activism in adulthood, empowers individuals to maintain their beliefs amidst societal changes. This potential function remains, however, a hypothesis at this stage; future research may provide a more thorough analysis of the relationship between activism and stability in political worldviews.

Finally, the recent trends of increasing right-wing identification and decreasing engagement among men, and left-leaning adults in general, seem to have changed the relationship between political orientation and engagement between our two adulthood data-gathering waves. By 2017, left-leaning women were no longer more active than right-leaning women, while right-leaning men became more active than leftleaning men. This may also be explained by the recent decline in left-wing politics in Germany, similar to other European countries (Anheier \& Weßels, 2015), or a weakening of political identities in Western democracies. This is manifested in increasing instability in political preference, growing dissatisfaction with (and lack of trust in) traditional politics, and eroding social cohesion in contrast to the growing importance of personal identities. In Germany, a gradual process of partisan dealignment was observed at the end of the twentieth century, which may also contribute to instability in self-placement along the political continuum (Becker \& Saalfeld, 2006). 
Some limitations of the analysis presented in this chapter must be considered. First, our data were not immune to common difficulties inherent to longitudinal endeavors, such as substantial (though not necessarily selective) attrition. Although we have attempted to expose causal relationships, we should emphasize that the study was observational and correlational in nature. We merely exposed relationships between past and present level of political engagement and were unable to point out the role of other potentially important environmental and psychological variables in determining political engagement in adulthood, as well as in intervening in the sequences between adolescence and adulthood participation. We can only hope that future research will attempt to increase the scope of our understanding of the factors that influence political participation across the lifespan.

Second, the readers must keep in mind the presumably limited external validity of the findings. The data were obtained from a population of peace-prone individuals with a high level of educational attainment at the onset of the study, thus not likely to be representative for the wider West German mid-1960s to mid-1970s cohort (see Boehnke \& Boehnke, 2005). Consequently, the result must be interpreted in light of parallel results from other samples and regions. Second, one of the weaknesses of this study is the absence of potential mediators of the examined effects. More research is needed to explicate causal mechanisms which may be at work in linking early-life and adulthood engagement. Lastly, general, single-item measures of activism and engagement were utilized herein, largely ignoring length, intensity, and types of engagement with politics. One must also consider the rapidly changing multidimensional nature of political engagement (both between and within conventional and nonconventional forms) and the possible differential mechanisms and effects involving each form (see Van Deth, 2014). Future research may differentiate between those dimensions of activism, which possibly involve different motivational factors and long-term outcomes.

Concerning the implications of this research to the practice of civic and political engagement among adolescence and youth, given the partial-yet-positive associations found between early-life activism and adulthood engagement, as well as the potential function of activism in strengthening pro-peace attitudes, we can only recommend that communities involve adolescence and youth in politics. The rationale is clear: for a polity to remain vibrant and open to transformations, future generations (and especially those who traditionally had less space in the political arena) must be empowered with the experience of agency. This is particularly so for non-male, non-majority constituents.

This might, as it seems, instigate a lifetime of political involvement. It is also worth repeating the recommendation given by Flanagan (2009): to facilitate lifelong effects of civic engagement, it is not enough to engage adolescents in activism; one must also ensure that such activities enable them to explore diverse perspectives and develop efficacious attitudes toward politics. What seems of particular import is an offering that is life-course-sensitive. Such an offering should facilitate activism across life-course transitions. Transitions seem to be powerful stumbling blocks of political activism. When people leave tertiary education, enter the job market, become a parent, etc., these life events 
pose challenges to political activism continuance. Life-course transitions, thus, need special attention also by civil society agents.

The current findings add to the growing research on the importance of ensuring that gender equality and sustainability are supported by the voices of those most affected. Political engagement matters most for those policies which guard against adverse life-course events (e.g., social protection), and as such, empowerment is a necessary (though by no means sufficient) element of sustainable communities.

Considering future research, bridging political and peace psychology with developmental perspectives still requires longitudinal research, preferably following developmental pathways of socialization and change across the lifespan. Ideally, it would be beneficial to have data prior to the onset of political activity and partisanship in adolescence, not least to enable researchers to rule out selection effects.

\section{References}

Abramowitz, S., \& Nassi, A. (1981). Keeping the faith: Psychosocial correlates of activism persistence into middle adulthood. Journal of Youth and Adolescence, 10, 507-523.

Amnå, E. (2012). How is civic engagement developed over time? Emerging answers from a multidisciplinary field. Journal of Adolescence, 35(3), 611-627.

Anheier, H. K., \& Weßels, B. (2015). Political culture, political satisfaction and the rollback of democracy. Global Policy, 6, 93-105.

Arnett, J. J. (2006). Emerging adulthood in Europe: A response to Bynner. Journal of Youth Studies, 9(1), 111-123.

Ballard, P. J., \& Ozer, E. J. (2016). The implications of youth activism for health and well-being. In J. Conner \& S. M. Rosen (Eds.), Contemporary youth activism: Advancing social justice in the United States (pp. 223-243). Santa Barbara, CA: Greenwood.

Bandura, A. (1969). Social-learning theory of identifactory processes. In D. A. Goslin (Ed.), Handbook of socialization: Theory and research (pp. 213-261). New York, NY: Rand McNally \& Company.

Barr, D., \& Drury, J. (2009). Activist identity as a motivational resource: Dynamics of (dis)empowerment at the G8 direct actions, Gleneagles, 2005. Social Movement Studies, 8, 243-260.

Beaumont, E. (2010). Political agency and empowerment: Pathways for developing a sense of political efficacy in young adults. In L. R. Sherrod, J. Torney-Purta, \& C. A. Flanagan (Eds.), Handbook of research on civic engagement in youth (pp. 525-558). Hoboken, NJ: Wiley.

Becker, J. C. (2012). The system-stabilizing role of identity management strategies: Social creativity can undermine collective action for social change. Journal of Personality and Social Psychology, 103(4), 647.

Becker, J. C., \& Tausch, N. (2015). A dynamic model of engagement in normative and nonnormative collective action: Psychological antecedents, consequences, and barriers. European Review of Social Psychology, 26(1), 43-92.

Becker, R., \& Saalfeld, T. (2006). Continuity and change of party identification in Germany, 19862000: A contribution to construct validation using longitudinal data. Paper presented at the ECPR Join Sessions of Workshops, Nicosia, Cyprus, 25-29 April 2006.

Blackwood, L. M., \& Louis, W. R. (2012). If it matters for the group then it matters to me: Collective action outcomes for seasoned activists. British Journal of Social Psychology, 51(1), 72-92.

Boehnke, K. (2017). Ist Rechtsextremismus „erblich“? Zur Ähnlichkeit rechtsextremer Verhaltenstendenzen von Studierenden und ihren Eltern [Is right-wing extremism ,inheritable'? On the similarity of right-wing extremist behavioral tendencies among university students and their parents]. Zeitschrift für Familienforschung, 29(3), 340-354. 
Boehnke, K., \& Boehnke, M. (2005). Once a peacenik - always a peacenik? Results from a German six-wave, twenty-year longitudinal study. Peace and Conflict: Journal of Peace Psychology, 11, 337-354.

Boehnke, K., \& Wong, B. (2011). Adolescent political activism and long-term happiness: A 21-year longitudinal study on the development of micro-and macrosocial worries. Personality and Social Psychology Bulletin, 37(3), 435-447.

Boehnke, K., Sohr, S., \& Stromberg, C. (2016). "Politische Persönlichkeiten" - eine aussterbende Spezies? [Political personalities - an endangered species?]. In A. Gürlevik, K. Hurrelmann \& C. Palentien (Eds.), Jugend und Politik (pp. 227-253). Wiesbaden, Germany: Springer VS.

Bogaards, M., \& Deutsch, F. (2015). Deliberation by, with, and for University Students. Journal of Political Science Education, 11(2), 221-232.

Childs, S. (2004). A British gender gap? Gender and political participation. The Political Quarterly, 75(4), 422-424.

Corbetta, P. G., Tuorto, D., \& Cavazza, N. (2013). Parents and children in the political socialisation process: Changes in Italy over thirty-five years. In S. Abendschon (Ed.), Growing into politics: Context and timing of political socialization (pp. 11-32). Colchester, UK: Ecpr Press.

Delli Carpini, M. (2006). Generational replacement. In L. Sherrod, C. A. Flanagan, R. Kassimir, \& A. K. Syvertsen (Eds.), Youth activism: An international encyclopedia (pp. 282-284). Westport, CT: Greenwood.

Drury, J., \& Reicher, S. (2005). Explaining enduring empowerment: A comparative study of collective action and psychological outcomes. European Journal of Social Psychology, 35(1), $35-58$.

Drury, J., \& Reicher, S. (2009). Collective psychological empowerment as a model of social change: Researching crowds and power. Journal of Social Issues, 65, 707-725.

Easton, D. (1968). The theoretical relevance of political socialization. Canadian Journal of Political Science/Revue canadienne de science politique, 1(2), 125-146.

Erikson, E. H. (1968). Identity: Youth and crisis. New York, NY: W.W. Norton.

Fendrich, J., \& Lovoy, K. (1988). Back to the future: Adult behaviour of former student activists. American Sociological Review, 53, 780-784.

Fischer, C. (2001). "Das gehört jetzt irgendwie zu mir." Mobilisierung von Jugendlichen aus den neuen Bundesländern zum Engagement in einem Umweltverband. Eine Fallstudie am Beispiel der BUNDjugend ["Somehow this now belongs to me." Mobilization of adolescents towards engagement in an environmental association in the new federal states. A case study of BUNDjugend]. Chemnitz: unpublished doctoral dissertation. Retrieved from http://monarch. qucosa.de/fileadmin/data/qucosa/documents/4480/data/Index3.html

Flanagan, C. (2009). Young people's civic engagement and political development. In A. Furlong (Ed.), International handbook of youth and young adulthood: New perspectives and agendas (pp. 293-300). New York, NY: Routledge.

Flanagan, C., \& Levine, P. (2010). Civic engagement and the transition to adulthood. The Future of Children, 20(1), 159-180.

Flanagan, C. A., \& Tucker, C. J. (1999). Adolescents' explanations for political issues: Concordance with their views of self and society. Developmental Psychology, 35(5), 1198-1209.

Flanagan, C. A. (2013). Teenage citizens: The political theories of the young. Harvard, IL: Harvard University Press.

Franz, C., \& McClelland, D. (1994). Lives of women and men active in the social protests of the 1960s: A longitudinal study. Journal of Personality and Social Psychology, 66(1), 196-205.

Inglehart, R., \& Klingemann, H.-D. (1976). Party identification, ideological preference, and the left-right dimension among Western mass publics. In I. Budge, I. Crewe, \& D. Farlie (Eds.), Party identification and beyond (pp. 243-273). London, UK: Wiley.

Jennings, M. K., \& Niemi, R. G. (1974). The political character of adolescence: The influence of families and schools. Princeton, NJ: Princeton University Press.

Jennings, M. K., \& Niemi, R. G. (1981). Generations and politics. Princeton, NJ: Princeton University Press. 
Jennings, M. K., \& Stoker, L. (2004). Social trust and civic engagement across time and generations. Acta Politica, 39, 342-379.

Jennings, M. K., Stoker, L., \& Bowers, J. (2009). Politics across generations: Family transmission reexamined. Journal of Politics, 71(3), 782-799.

Kaplan, H., \& Liu, X. (2000). Social protest and self-enhancement - a conditional relationship. Sociological Forum, 15(4), 595-616.

Klar, M., \& Kasser, T. (2009). Some benefits of being an activist: Measuring activism and its role in psychological well-being. Political Psychology, 30(5), 755-777.

Kunst, J. R., Boos, B., Kimel, S. Y., Obaidi, M., Shani, M., \& Thomsen, L. (2018). Engaging in extreme activism in support of others' political struggles: The role of politically motivated fusion with out-groups. PLoS One, 13(1), e0190639.

Levine, P. (2007). The future of democracy: Developing the next generation of American citizens. Medford, MA: Tufts University Press.

Loader, B., Vromen, A., \& Xenos, M. (2014). The networked young citizen: Social media, political participation and civic engagement. New York, NY: Routledge.

Matsuba, J. K., Hart, D., \& Atkins, R. (2007). Psychological and social-structural influences on commitment to volunteering. Journal of Research in Personality, 41, 889-907.

McFarland, D. A., \& Thomas, R. J. (2006). Bowling young: How youth voluntary associations influence adult political participation. American Sociological Review, 71(3), 401-425.

McIntosh, H., Hart, D., \& Youniss, J. (2007). The influence of family political discussion on Youth Civic Development: Which parent qualities matter? PS: Political Science and Politics, 40(3), 495-499.

Norris, P. (2011). Democratic deficit: Critical citizens revisited. New York, NY: Cambridge University Press.

Ojeda, C., \& Hatemi, P. (2015). Accounting for the child in the transmission of party identification. American Sociological Review, 80(6), 1150-1174.

Otto, A. H., \& Steinhardt, M. F. (2017). The relationship between immigration and the success of far-right political parties in Germany. DICE Report, 15(4), 20-23.

Petri, H., Boehnke, K., Macpherson, M. J., \& Meador, M. (1986). Bedrohtheit bei Jugendlichen [The feeling of threat among adolescents]. Psychosozial, 9(29), 62-71.

Portney, K. E., Eichenberg, R. C., \& Niemi, R. G. (2009). Gender differences in political and civic engagement among young people. Paper presented at the Annual Meeting of the American Political Science Association, Toronto, Canada, September 2009.

Quintelier, E. (2015a). Engaging adolescents in politics: The longitudinal effect of political socialization agents. Youth \& Society, 47(1), 51-69.

Quintelier, E. (2015b). Intergenerational transmission of political participation intention. Acta Politica, 50(3), 279-296.

Rico, G., \& Jennings, M. K. (2016). The formation of left-right identification: Pathways and correlates of parental influence. Political Psychology, 37(2), 237-252.

Sears, D. O., \& Funk, C. L. (1999). Evidence of the long-term persistence of adults' political predispositions. The Journal of Politics, 61(1), 1-28.

Settersten, R. A., Jr., Furstenberg, F. F., \& Rumbaut, R. G. (Eds.). (2008). On the frontier of adulthood: Theory, research, and public policy. Chicago, IL: University of Chicago Press.

Shriver, T. E., Miller, A. C., \& Cable, S. (2003). Women's work: Women's involvement in the Gulf War illness movement. The Sociological Quarterly, 44(4), 639-658.

Thomas, E. F., \& Louis, W. R. (2013). Doing democracy: The social psychological mobilization and consequences of collective action. Social Issues and Policy Review, 7(1), 173-200.

Van der Eijk, C., Schmitt, H., \& Binder, T. (2005). Left-right orientations and party choice. In J. Thomassen (Ed.), The European voter: A comparative study of modern democracies (pp. 167-191). Oxford, UK: Oxford University Press.

Van Deth, J. W. (2014). A conceptual map of political participation. Acta Politica, 49(3), 349-367.

Verba, S. (2003). Would the dream of political equality turn out to be a nightmare? Perspectives on Politics, 1(4), 663-679. 
Verba, S., \& Nie, N. H. (1972). Participation in America: Political democracy and social equality. New York, NY: Harper \& Row.

Verba, S., Scholzman, K. L., \& Brady, H. E. (1995). Voice and equality: Civic voluntarism in American politics. Cambridge, MA: Harvard University Press.

Vestergren, S., Drury, J., \& Chiriac, E. H. (2017). The biographical consequences of protest and activism: A systematic review and a new typology. Social Movement Studies, 16(2), 203-221.

Vollebergh, W. A. M., Iedema, J., \& Raaijmakers, Q. A. W. (2001). Intergenerational transmission and the formation of cultural orientations in adolescence and young adulthood. Journal of Marriage and Family, 63(4), 1185-1198.

Vraga, E. K., Bode, L., Yang, J., Edgerly, S., Thorson, K., Wells, C., \& Shah, D. V. (2014). Political influence across generations: Partisanship and candidate evaluations in the 2008 election. Information, Communication \& Society, 17(2), 184-202.

Welzel, C., \& Deutsch, F. (2012). Emancipative values and nonviolent protest: The importance of 'ecological' effects. British Journal of Political Science, 42(2), 465-479.

Open Access This chapter is licensed under the terms of the Creative Commons Attribution 4.0 International License (http://creativecommons.org/licenses/by/4.0/), which permits use, sharing, adaptation, distribution and reproduction in any medium or format, as long as you give appropriate credit to the original author(s) and the source, provide a link to the Creative Commons license and indicate if changes were made.

The images or other third party material in this chapter are included in the chapter's Creative Commons license, unless indicated otherwise in a credit line to the material. If material is not included in the chapter's Creative Commons license and your intended use is not permitted by statutory regulation or exceeds the permitted use, you will need to obtain permission directly from the copyright holder.

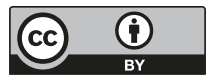

